\title{
INTEGRATING THE ENVIRONMENT IN LOCAL STRATEGIC PLANNING : GUIDELINES (CASE OF MOROCCO)
}

\author{
Hafsa BENBRAHIM* \\ Phd Researcher \\ Laboratory Environment, Oceanology and Natural Resources (LEORN), \\ Faculté des Sciences et Techniques de Tanger-Université Abdelmalek Essaâdi, \\ BP. 416, Tangier, Morocco.
}

\begin{abstract}
Since 2010, an advanced regionalization project has been initiated by Morocco, which plans to consolidate the processes of decentralization and deconcentration by extending the powers of the regions and other local authorities. This project, institutionalized in the 2011 Constitution, defines the territorial organization of the Kingdom and reinforces decentralization according to a model of advanced regionalization. Through advanced regionalization, Morocco aims at integrated and sustainable development in economic, social, cultural and environmental terms, through the development of the potential and resources of each region. However, in order to honor this commitment of advanced regionalization, local authorities must be assisted in adopting a local strategic planning approach, allowing them to develop territorial plans for sustainable development in accordance with the national legal framework, specifically the Framework law 99-12, and international commitments in terms of environmental protection.

This research deals with the issue of environmental governance in relation to the role and duties of local authorities. Thus, the main goal of our study is to present the guidelines to be followed by the local authorities to improve the quality of the environment integration process in the local strategic planning with the aim of putting it in a perspective of sustainable development.
\end{abstract}

Key words : Sustainable Development, Local Environmental Integration, Territorial Strategic Planning.

*Corresponding author: $\underline{\text { hafsabenbrahim@yahoo.com }}$ 


\section{Introduction}

The role of territorial communities in the process of implementing sustainable development was affirmed at the United Nations Conference on Environment and Development in Rio (1992): «It is local communities that build, monitor the planning processes, set local environmental guidelines and regulations, and support the implementation of environmental policies at the national or sub-national level. They play at the administrative level closest to the population, a key role in education, mobilization and taking into account public views for sustainable development» [1].

Agenda 21, for this purpose, suggests in Chapter $28^{1}$ that local authorities also need to prepare action's strategies that respond, on their own scale, to the concern for sustainable development. These initiatives can be considered as an action plan resulting from the reflections made around the postulate of sustainable development and which the purpose is the integration of this vision in the management of local communities [1].

However, implementing sustainable development as a local public policy is problematic: Local and regional authorities are key players, but they intervene in increasingly large fields and face a growing complexity of the policies for which they are responsible. As a result, they do not always have the appropriate knowledge, forecasting and action tools to implement it. Thus, the integration of sustainable development requires a gradual and continuous learning and improvement process, under which sustainable development integrates, simultaneously and transversally, the economic, environmental and social dimensions into any development project, as well as their interrelations in order to find the best balance or the best possible compromise.

Sustainable development introduces new logics of transversality, long-term and participation, particularly in the objectives and practices of public action [2]. While the very definition of sustainable development is debated, a consensus seems to have emerged on the need to act locally to solve a global problem.

The territorial approach is gradually becoming an essential component of the implementation of sustainable development, especially since the diversity of its stakes can hardly be taken into account on a global scale. It is a multidimensional concept, based on the reconciliation of economic, social and environmental issues that can be contradictory. And since the operational translation of these dimensions leaves large place for interpretation, one can think that there is no sustainable development but rather sustainable developments that respond to the specificities of each territory. This territorialisation reinforces, moreover, one of the founding principles of sustainable development, that of the participation of actors in development policy. Various forms of participation have been highlighted in the work of REY-VALETTE et al. [2] and ANDRES and FARACO [3]. While at a global scale, the sustainable development process is based on a normative approach based on values accepted by all (convergence of discourses), its implementation at the lower levels is closely linked to the individual and collective visions of the decisionmaking actors (experts, politicians, citizens, etc.) and the specificities of the territory (geographic situation, economic and social specificities, etc.).

\footnotetext{
${ }^{1}$ http://www.un.org/french/ga/special/sids/agenda21/action28.htm
} 
For DECAMPS and VICARD [4], the application of the principles of sustainable development at the national and regional scales follows a procedural approach, its dimensions being then declined according to more precise orientations, and defined by actors pursuing a common general interest. Similarly, the implementation of sub-regional sustainable development is a collaborative, compromise-based approach in response to the particular interests of stakeholders. The issues of sustainable development are then broken down into consensual actions, adapted to the specificities of their territory and to the objectives and practices of local actors. Although the interest of a territorialisation of sustainable development is no longer demonstrated, it nonetheless leads to obvious complexification. Sustainable development is still a difficult concept to make operational for local authorities, which results in a great heterogeneity of implementation methodologies.

As a pillar of sustainable development, the environment has been in fact for several decades, and still remains today, a "laboratory" where new forms of governance are constantly being invented: democratic consultation procedures, flexible forms of coordination, modes of decentralized management. Various examples attest to this effort to modernize public action: "Agendas 21", "impact studies", "voluntary agreements", "rights to pollute markets", "independent authorities", "conferences" consensus ","precautionary principle "," sustainable development "," negotiated standards or agreements "..., etc. This trend obviously accelerated at the turn of the $90 \mathrm{~s}$, in a context marked by globalization, the emergence of major economic regions such as Europe, and the growing influence of liberal ideas, to the point that one can speak retrospectively of a true "silent revolution" in the design and implementation of environmental policies [5] .

If we take the case of Morocco, which since 2010 has experienced an unprecedented dynamism especially in terms of governance, many reform projects are indeed committed to endorse the process of democratization of society and guide the search for a sustainable development model at the national; regional and local level. Under these reforms, and in accordance with the Article 2 of the Framework law 99-12 [6], bearing the Charter of the Environment and Sustainable Development (CNEDD), the local authorities are called to take into account the objectives of State's action in terms of environmental protection and sustainable development in their strategies for developing and implementing development plans. This implies that the communal planning process needs to be revised to align more closely with the fundamental principles, rights and duties of sustainable development in accordance with Article 1 of the Framework law 99-12 [6]. Thus, territorial authorities have to watch quite particularly to adopt a global, intersectorial and transverse approach allowing to take into account environmental stakes in the elaboration of the visions and the plans of local development.

The integration of the environment into municipal planning is now recognized as an essential requirement to put local Action in the path of sustainable development. The main national references in terms of environmental integration and sustainable development are respectively the provisions contained in the 2011 Constitution [7], and in particular the Framework law 99-12, bearing Charter of Environment and Sustainable Development (CNEDD) [6]. In response to these legal references, it is fundamental to renew the tools and methods adopted so far in the context of municipal planning, to base this process on 
sustainable long-term visions and on strategic choices that are aligned perfectly for the purposes of sustainable development on a local scale.

The promulgation of the Framework law 99-12 represented a real achievement for the Moroccan legal framework in terms of protection of the environment and sustainable development at the national level. It constitutes a true legal reference for the decisionmakers, planners and executors of public policies whose main aim is to decline and operationalize the National Charter of the Environment and Sustainable Development (CNEDD), by giving a legal basis to its content. This framework law establishes the principles, the rights, the duties and the commitments, proclaimed by the CNEDD, which aims at inscribing the processes of elaboration, implementation and monitoring-assessment of the strategies, as well as sectoral policies, programs and action plans in strict compliance with the requirements of environmental protection and sustainable development.

It should be noted that one of the important aspects of this framework law is that it defines the responsibilities and commitments that all stakeholders (State, local authorities, public institutions, private companies, civil society associations and citizens) must respect in terms of environmental protection and sustainable development.

\section{Methodology :}

Our approach of integration of the environment in the local strategic planning, is based on a qualitative analysis which takes as frame of reference:

$>$ The National Charter of the Environment and Sustainable Development [6] which becomes the reference framework for the development of any territorial project;

$>$ The new Constitution [7] and the process of advanced regionalization, which require a strong commitment of local authorities that allows them to dispose consequently of a broader decision-making and executive powers that should enable them to perform their duties and to honor their new responsibilities;

$>$ The National Initiative for Human Development [8], which aims to struggle against poverty, exclusion and territorial disparities, and which intervenes mainly in the most vulnerable areas in both urban and rural areas;

$>$ And finally, the broad project of support and accompaniment of the communes in the elaboration of their Communal Development Plan (PCD) [9]: "The commune at the 2020 horizon" which aims to make local authorities a locomotive of development at the local level, provincial and regional.

Our aim is to bring together the findings, to establish a reading grid on the integration of the 'environment' component in strategic planning at the local level under the territorial variation of the national environmental policy in a strategic and prospective framework.

\section{Results and discussion}

Our research aims to highlight guidelines for integrating the environment into local strategic planning, which challenges consequently the concept of environmental governance in relation to the role and duties of territorial communities. 


\subsection{Fundamental principles of environmental integration}

Seven fundamental principles, in terms of environmental integration and sustainable development, are set out in Article 2 of the framework law 99-12, bearing Charter of Environment and Sustainable Development (CNEDD). These principles, considered as essential elements of framing that must be respected by local authorities and other levels of decision-making (national and regional) in any medium and long-term development action, are:

1. The principle of integration: it implies the need to adopt a global and transversal approach when drawing up and implementing development plans in the medium and long term;

2. The principle of territoriality: it imposes the taking into account of the territorial dimension, in particular the regional one, in order to ensure a better articulation of the measures initiated by the different levels of territorial decisions and to encourage the mobilization of the actors in favor of human development, sustainable and balanced territories;

3. The principle of solidarity: it allows to increase the capacity of the territory to face the vulnerabilities and to favor a rational, economical and balanced use of natural resources and spaces;

4. The precautionary principle: it recommends that adequate, economically viable and acceptable measures be taken to deal with environmental damage or potential risks, even in the absence of absolute scientific certainty about their real impacts;

5. The principle of prevention: it invites to provide tools for regular assessment and assessment of the impacts of activities likely to harm the environment, to recommend and implement concrete measures to eliminate these impacts, or at least reduce their negative effects;

6. The principle of responsibility: it specifies the obligation of any person, physical or moral, public or private, to repair the damage caused to the environment;

7. The principle of participation: it encourages the active participation of companies, civil society associations and the public in the process of developing and implementing plans for environmental protection and sustainable development.of participation.

The adoption of these fundamental principles of the Framework law 99-12 is aimed primarily at bridging existing legal gaps in the integration of the environment into strategies, policies, programs and action plans. At local authority levels, it lays the foundations for a new generation of communal development plans, based on a global, cross-sectoral and transversal approach, enabling to achieve sustainable territorial development in the long term.

\subsection{Foundations of the integration approach of Environment and Sustainable Development at the local scale}

According to Article 20 of Framework law 99-12, regions and other local authorities must ensure that the principles and objectives of environmental protection and sustainable development are integrated into planning tools and programs related to their respective territories. 
On this basis, the Local Environment Integration (IEL) and Sustainable Development approach sets itself as key objectives to help local authorities respectively to:

$>$ Base the communal planning process on the fundamental principles and objectives of environmental protection and sustainable development stated in the Framework law 99-12 (CNEDD);

$>$ Basing communal planning on a vision shared by the populations, in the long term, which reconciles the economic, social and cultural objectives of the development activities and the issues of environmental protection of the territory;

$>$ Articulate municipal planning with national strategies, policies and conventions related to human development and environmental protection;

$>$ Integrate in the communal planning, at a time environmental protection and the valorization of environmental services, according to an ecosystem approach, while promoting the effects of synergy, subsidiarity and pooling of intercommunal efforts.

These key-objectives form the framework's elements subtending the guidelines to regulate and govern the communal planning process, but also permits to integrate systematically the environmental dimension and to suscribe the communal planning in a local sustainable development perspective. These elements of framing require that the new generation of Communal Development Plans (PCD) adopts respectively:

- a global, intersectoral and transversal approach;

- $\quad$ an active participation process;

- a relevant spatial scale;

- $\quad$ inter-municipal and regional solidarity;

- a high level commitment;

- a simple and practical environmental assessment tool;

- $\quad$ a strategy to mitigate potential risks.

\subsection{Constitutive phases of the Integration approach of Environment at the local scale}

The environmental integration approach (IEL) in municipal planning has four main stages, which are organized, according to the communal planning process, recommended by the General Directorate of Local Communities's guide (DGCL guide) [10], as follows:

$>$ Stage 1: Integration of the environment into the preparation stage and into the launch of the Communal Development Plans (PCD);

$>$ Stage 2: Integration of the environment into the participatory diagnosis stage;

$>$ Stage 3: Integration of the environment into the planning, programming and putting in coherence stage;

$>$ Stage 4: Integration of the environment in the Communal Information System (SIC). 
In terms of discussion, and after having put forward the principles and foundations of the environmental integration approach in local strategic planning (IEL), it results that its application to the municipal planning process aims at three essential objectives:

1. Identify, understand and prioritize the environmental issues that are decisive for the future of the territory, and identify their interdependencies with the rest of the economic, social and cultural components;

2. Integrate, according to a participatory and transversal approach, the priority environmental issues of the territory, in the construction of the vision of development and in the programming of the actions;

3. Monitor progress made in integrating environmental issues into municipal planning, based on territorialized sustainable development indicators.

According to these objectives, it appears that the notion of environmental issue is at the heart of the "IEL" approach. And the environmental issue implies, at this level, any change in the state of the environment that significantly influences the future of the territory, and which often involves an ecosystem service, useful for the current and future social wellbeing, that it is not acceptable to see the disappearance or degradation, from the point of view of natural resources, public health or quality of life.

\section{Conclusion :}

The construction of a territorial project for sustainable development in Morocco requires the systematic consideration of interdependencies between the economic, social, cultural and environmental dimensions. The Local Environment Integration and Sustainable Development approach (IEL approach) should engage local and regional authorities in a process of continuous improvement, allowing to respond simultaneously to at least four types of essential needs:

1. Reconcile the short-term economic, social and cultural objectives with the decisive environmental issues of the territory and with the perspective of sustainable development in the long term;

2. Promote the active participation, commitment and responsiveness of local stakeholders and their partners in the territory, throughout the process of building and implementing the vision of sustainable development;

3. Use the relevant environmental information to forecast, anticipate and take the appropriate measures that are aligned with and fully meet the objectives of sustainable territorial development;

4. To dispose of monitoring tool which allow to report on local authorities efforts undertaken in terms of environmental protection and valorization of environmental services. 


\section{References :}

- [1] UNCED, Agenda 21, The United Nations Program of Action from Rio, New York, United Nations Development Program (1992) : https://sustainabledevelopment.un.org/content/documents/Agenda21.pdf

- [2] Rey-Valette H., Laloë Francis, Le Fur Jean, Roussel S. (2006). Usages des indicateurs de développement durable: entre offre et demande d'indicateurs. SaintQuentin-en-Yvelines: IRD-UVSQ, 15 p. multigr. Colloque GECOREV.Gestion Concertée des Ressources Naturelles et de l'Environnement, du Local au Mondial, Saint Quentin en Yvelines (FRA), 2006/06/26-28.

- [3] L. Andres, B. Faraco, La territorialisation des normes du développement durable. Agenda 21 locaux : vers un modèle explicatif des différenciations », in A. FAURE et E. NEGRIER, Les politiques publiques à l'épreuve de l'action locale, Critiques de la territorialisation, L'Harmattan, Paris, (2007).

- [4] M. Decamps, F. VICARD, Mesurer le développement durable: jeux d'indicateurs et enjeux locaux. Revue d'Économie Régionale \& Urbaine, 4 (2010).

- [5] W.D. SUNDERLIN, Global environmental change, sociology and paradigm isolation. Global environmental change, 5 (1995).

- [6] Loi n 99-12 portant Charte de l'Environnement et du Développement Durable http://www.environnement.gov.ma/PDFs/loi_cadre_fr.pdf

- [7] Secrétariat Général du Gouvernement, La Constitution, édition 2011, Série Documentation juridique marocaine, (2011).

- [8] Conseil Économique, Social et Environnemental, Initiative Nationale pour le Développement Humain: analyse et recommandations. Saisine, 2 (2013).

- [9] Ministère de l'intérieur, Projet de guide pour l'élaboration du Plan Communal de Développement (PCD) selon l'approche de planification strategique participative, Direction Générale des Collectivités Locales, (2008).

- [10] Ministère Délégué auprès du Ministère de l'Energie, des Mines, de l'Eau et de l'Environnement, chargé de l'Environnement, Guide pour l'intégration de l'environnement dans la planification communal, (2014).

\section{Complementary references:}

- A. Boutaud, Le développement durable : penser le changement ou changer le pansement? Bilan et analyse des outils d'évaluation des politiques publiques locales en France : de l'émergence d'un changement dans les modes de faire au défi d'un changement dans les modes de penser, Thèse de doctorat, Science et génie de l'environnement, Ecole des Mines de St Etienne-Université J. Monnet, St Etienne, (2005).

- A.Fouquet, J. Perriault, Évaluation, politiques publiques, politique de recherche. Communication et Organisation, 38 (2010). 
- F. Bertrand, Planification et développement durable : vers de nouvelles pratiques d'aménagement régional ? L'exemple de deux Régions françaises, Nord-Pas-de-Calais et Midi-Pyrénées. Géographie. Université François Rabelais-Tours, (2004). [manuscrit disponible en ligne : http://tel.ccsd.cnrs.fr/tel-00012142].

- F. Rudolf, J. kosman, Le développement durable entre programme d'action et applications? , Ecologie et politique, 29 (2004).

- $\quad$ G.H. Bruntland, Notre avenir à tous (Our Common Future), Rapport de la Commission des Nations-Unies pour l'Environnement et le Développement (CNUED), Editions du Fleuve, Québec, (1987).

- J. Theys, La Gouvernance, entre innovation et impuissance, Développement durable et territoires 2 (2003). URL : http://developpementdurable.revues.org/1523; DOI : 10.4000/developpementdurable.1523.

- MEDD/PUCA programme «Politiques territoriales et développement durable » [http://citeres.univ-tours.fr//p_vst/contrats/D2RTrapportfinal.pdf]. 